\title{
Conscientious objection, harm reduction and abortion care
}

\author{
Ruth Fletcher
}

\begin{abstract}
A forthcoming chapter in Mary Donnelly and Claire Murray (eds.) Ethical and Legal
Debates in Irish Healthcare: Confronting Complexities (Manchester University Press,
\end{abstract} 2016).

[Note: This is the pre-publication version, which has been updated in light of the UKSC decision in Doogan and Wood (2014)]

\section{Introduction}

The scope of any legal right to refuse abortion care merits particular consideration given the recent passing of the Protection of Life During Pregnancy Act 2013 (PLDPA) and ongoing demand for abortion reform. Irish health scholarship and practice may benefit from an account of conscientious objection (CO) that clarifies when $\mathrm{CO}$ is legitimately engaged by a refusal to provide care and whether $\mathrm{CO}$ is limited given its potential effect as a barrier to women's lawful access to abortion. This chapter responds to these concerns by arguing for a harm reduction approach to conscientious objection. Those who wish to refuse provision of healthcare in spite of a legal obligation, and those who wish to provide healthcare in spite of a legal prohibition, may be harmed by having to act against their most intimate convictions. Moreover, public reasoning about the proper scope of healthcare provision could be disadvantaged by a failure to recognize a 
space for critical consciousness. The need to reduce the risk of harm to women, whose lawful entitlement to access abortion has been hard-won, also animates the justification for legal limits on CO. In arguing for a harm reduction approach, the account offered here draws on but distinguishes itself from those who have relied on public obligations to refute $\mathrm{CO}$ and those who have relied on an individual right to moral integrity to ground $\mathrm{CO}$.

\section{Conscientious objection and critical consciousness}

Some believe that healthcare professionals should not be able to refuse healthcare on grounds of conscience (Savulescau, 2006; Gallagher et al, 2013: 6; Kelleher, 2010; Fiala and Arthur, 2014) and that CO operates simply as an obstacle to women's access to healthcare (Thomson, 2013). Their argument is that the duty to provide public healthcare requires that providers put their personal views and opinions to one side. If acting on one's personal views in refusing to provide healthcare is done for discriminatory or otherwise harmful reasons, I agree that this is not acceptable. But it is obviously not unacceptable in itself to act on one's personal commitments in the context of providing healthcare (Dickens, 2014: 212). Secondly, requiring health professionals to act against their conscience when another alternative is available, risks taking much of the good out of the duty to care. If, as Campbell (2011a) notes, the effect of this is that the genuine objector leaves healthcare the complete rejection of CO may be counterproductive. Thirdly, it is not good for those receiving healthcare to have to worry about the commitment of their healthcare provider to the healthcare sought. 
It would be better if the question of CO were openly addressed. As I argue below, there are considerable limits on $\mathrm{CO}$. But any legal test for the scope of $\mathrm{CO}$ ought to recognize that its objective is to prevent any psychological harm to healthcare providers that may occur if they are required to act in a way that goes against their moral choices and intimate convictions.

Others argue that conscientious objection in a health care context is a right which results from respect for the moral integrity of the individual (Wicclair, 2011; Campbell, 2011a). On this understanding, conscientious objection arises when preserving an individual's moral integrity requires the breaking of a legal norm. This is why the right to CO may be narrowly drawn. Everyone is under a duty to abide by legal norms and any derogation from a legal obligation to provide healthcare has to be restrictive (see further Montgomery, 2015). This approach to CO is important in identifying a violation of an individual's moral integrity as the harm which CO addresses and in implying a narrow scope for $\mathrm{CO}$ given its location as dissent within a framework of lawful norms. Scholars such as Dickens, Cook and Joffe have done important work in reminding us that conscientious responses in healthcare are not always refusals to provide healthcare and are not always motivated by a conservative or 'sanctity of life' approach to ethical questions (Dickens, 2014: 233-238, Cook and Dickens, 2011;

Dickens, 2006; Joffe, 1996). As Murphy noted recently in an Irish context, healthcare professionals also act out of a conscientious commitment to the provision of abortion care (2014). Pro-choice doctors see the harm which abortion restrictions have on women's lives and challenge legal failures to endorse abortion provision (Doctors for 
Choice, 2014). In this chapter, I draw these different threads together to argue for a reframing of $\mathrm{CO}$ as an exercise in critical consciousness within a harm reduction framework. I reflect on European Convention on Human Rights (ECHR) and comparative jurisprudence and policy in fleshing out a framework for interpreting the section 17 right in the PLDPA not to "carry out, or to assist in carrying out, any medical procedure referred to in section $7(1)$ or section $9(1)$ " on grounds of $\mathrm{CO}$. Both sections refer to medical procedures "in the course of which, or as a result of which, an unborn human life is ended."

\section{Bearers of critical consciousness}

The grounding of the right to conscientious objection in critical consciousness is an important factor in understanding why CO usually ought not apply to corporate persons (Sepper, 2012, 2013; Corbin, 2014). Although institutions may indeed have an ethos or a code of ethics, this is a matter of fact and results from a group's adoption of certain principles and values as that ethos. Ethos in this descriptive sense is qualitatively distinct from the consciousness which is part of the individual's critical and psychological being. Asking hospitals or corporate persons to act against their collective ethos or policy means asking those institutions to act against a rule they have adopted in a lawlike process. It does not entail asking them to act against an intimate, psychological commitment because institutions cannot have that critical faculty. As Sepper notes, the effect of asserting an institutional ethos will often be to downgrade the consciences of individuals providing care within that institution (2012). For Corbin the idea that 
corporations could be exempt from the provision of lawful abortion care on grounds of conscience is part of 'abortion exceptionalism', and should not be legally accepted (2014).

The PLDPA frees medical practitioners, nurses and midwives from the obligation to provide lawful abortion care on grounds of conscientious objection, and does not refer explicitly to hospitals. The exclusion of hospitals as corporate persons from the category of conscientious objectors has some support in ECHR jurisprudence as companies and associations cannot usually rely on the right to freedom of thought, conscience and belief under Article 9 (Company X v Switzerland (1979) 16 DR 85; Verein Kontakt-Information-Therapie v Austria (1988) 57 DR 81). Campbell suggests that this limit should be read literally and that it does not mean that hospitals (as distinct from companies) are excluded (2011a: 293). Rather he suggests that the test is whether the state can organize the health service is such a way as to accommodate institutional CO. However, I think that his interpretation goes to a different point about CO concerning the significance of its limitations. Here I make a prior point that institutions are generally not the kind of legal person who have a critical consciousness and that is why they should not fall within the scope of Article 9 in the first instance. This approach is supported by the reasoning of the Colombian Constitutional court in Decision T$388 / 2009$, on the grounds that hospitals cannot experience intimate and deeply-rooted convictions and might limit the freedom of individual employees (2014: 44). But it is not supported by the reasoning of the majority in the US Supreme Court decision in 'Hobby Lobby' (Burwell, Secretary of Health and Human Services et al v Hobby Lobby 
Stores Inc et al. 573 US_ (2014), nor by the European Parliamentary Assembly resolution 1763 (2010). 'Hobby Lobby' concerned a decision that corporate employers could 'engage in religious exercise' under the First Amendment's guarantee of freedom of religion. The capacity of corporate persons to so engage was crucial to deciding that they had a right to be exempt from providing health insurance coverage to employees in relation to certain contraceptives. Resolution 1763 protects hospitals and institutions, as well as individuals, against discrimination or coercion because of a refusal to perform an abortion (see further Campbell, 2011b). But the reasons for the Colombian Constitutional Court's position are more persuasive in my view (see further Melling and Lee, 2014).

When corporate persons such as religiously run hospitals have considerable institutional power, it is even more important to interrogate any claim that they are justified in refusing provision of lawful healthcare on grounds of conscience. The Irish legal context is complicated by the fact that Article 44.2 .5 of the Constitution protects the right of every religious denomination to manage its own affairs. Some commentators have argued that this denominational autonomy might apply to voluntary hospitals operating under a religious ethos (Whyte, 2013; Coen, 2013). Coen has argued that requiring the hospitals to perform abortions under the 2013 Act could be open to a constitutional challenge. He believes that publicly funded religious hospitals do not have to act in a manner which conflicts with their ethos (Coen, 2013). But Daly has argued that this interpretation "is based on an implausibly broad interpretation of religious freedom and denominational autonomy" (2013). According 
to Daly, denominations have the right to maintain institutions, but that does not make them immune from public regulation (see further Daly, 2012). Daly is concerned with the limits imposed on hospitals through their public obligations to provide health care, an issue I take up below. But as the Colombian ruling helps make clear, there is a prior point: Hospitals as a whole should not be recognized as the bearers of $\mathrm{CO}$ in the first place, and 'denominational authority' covers the management of a hospital's affairs according to a descriptive account of its ethos. The legal interest in denominational authority under the Irish Constitution does not justify the legal recognition of institutional $\mathrm{CO}$ since $\mathrm{CO}$ is not the kind of practice that fits within such a descriptive understanding of ethos. Moreover, recognizing institutional conscience could undermine protection of the consciences of individual employees within that institution.

This issue has become more concrete in Ireland in the wake of the passing of the PLDPA. Two prominent Catholic hospitals, the Mater and St Vincent's are named in the Act as hospitals authorized to provided terminations. One of the Board members of the Mater, Fr. Doran, stated publicly that he was concerned about the possibility of the Act requiring the Mater to perform abortions, as this would breach their ethos. In September 2013, the Mater announced that it would be complying with the terms of the PLDPA (Holland, 2013; O'Carroll, 2013b). Fr. Doran has since resigned from the Board. It would seem that the hospital has agreed to abide by the terms of the Act in its provision of public and private health care, and not to invoke some kind of collective CO to the performance of life-saving terminations which may not conform with Catholic doctrine. But the issue is bound to continue to be contested and has generated a great 
deal of media coverage and public commentary, including from an anti-choice campaigner who has called for the nuns in the Mater to take a test case (O'Brien, 2013). An understanding of $\mathrm{CO}$ as an exercise in critical consciousness may contribute to this debate by explaining why hospitals with a religious ethos are unlikely to qualify for CO.

\section{Good faith, non-discriminatory claimants}

Two other sets of issues to do with the nature of the claim to CO have arisen in an Irish context. The first concerns the genuineness of the objection. The second concerns whether non-direct participation in abortion care amounts to the carrying out, or the assistance in carrying out of abortions under the PLDPA, and gives rise to a right to CO. In this section, I review how these concerns may play out. I argue that the best way to frame such concerns about legitimacy is by asking whether refusers of care are invoking a good faith, non-discriminatory objection.

\section{Genuineness of $\mathrm{CO}$}

Usually the 'genuineness' of a refusal to provide abortion care is not scrutinized in itself, but refusers are asked to identify themselves and to give reasons so that arrangements to accommodate the conscientious refusal can be made. Conscientious refusers may be distinguished from 'obstructors' or those whose objection falls more readily within the category of civil disobedience. If someone wants to obstruct the provision of the lawful service by ostensibly participating in it but refusing to authorize abortion on the legal grounds available, then this is not conscientious refusal as normally understood. Rather 
the intention is to frustrate the system and the normal expectation is that this person would be held to account. Since civil disobedience is about drawing attention to an objection with a particular law by disobeying it and inviting the consequences, obstruction is closer to civil disobedience in kind than it is to conscientious objection. The obstructor is not a 'genuine' conscientious objector because she does not wish to withdraw from the health care provision to which she objects. This distinction may be relevant in responding to any possibility that medical professionals may 'obstruct' the delivery of legal abortion care by participating while having no intention of approving abortion care in individual cases (see further Casey, 2013).

As Raz has pointed out, recognizing a right to object "involves sanctioning some degree of public intrusion into the private affairs of individuals" (2009: 287-8) because the genuineness of a conscientious objector needs to be assessed to prevent abuse (see also Campbell 2011: 287). If someone is seeking to rely on CO in order to lessen their workload or because they would rather do something else, then she is not objecting as an exercise in critical consciousness and does not have a legitimate claim. Some objectors will want to be freed of a range of activities which they associate with an immoral purpose on grounds of complicity (Campbell, 2011: 300). This will be the case even if others think that associated actions are not necessary for abortion care and ought not be objectionable to the objector. In a sense Glasgow midwives Doogan and Wood asked the UK Supreme Court to take the genuineness of their objection to being complicit in abortion care seriously when they supervise, delegate and support abortion care (Greater Glasgow Health Board v Doogan and Wood [2014] UKSC 68; hereinafter 
Doogan and Wood: para 12; Neal, 2014; see further Dickens, 2014: 229-230). They were unsuccessful because the Court ruled that they were not participating in a "hands-on capacity" when engaged in managerial and supervisory tasks. However, the genuineness of such a sense of complicity is not the only factor in deciding whether $\mathrm{CO}$ is legitimately engaged.

\section{Non-direct participation}

The legal distinction between direct and indirect participation in health care is also relevant to considering the legitimacy of a claim to CO. Law has often excluded indirect participants from claiming $\mathrm{CO}$ on the basis that their participation in something they find morally objectionable has to be direct (Fletcher, 2014: 130-132). As Sepper explains "across philosophical traditions, the necessity and proximity of the objector for the alleged bad act and the severity of the consequences of the act are central to moral responsibility" (2014: 726). Direct participants have a legal right to CO because they are proximate and necessary to the activity, and because the consequences of denying them that right would be serious. This distinction has also informed professional regulation. The British Royal College of Nursing's Framework on the Termination of Pregnancy currently provides:

This right is limited only to the active participation in the termination of pregnancy where there is no emergency with regard to the physical or mental health of the pregnant woman... Nurses and midwives who have a conscientious objection must inform their employer at the earliest opportunity. Under the 
1990 legislation, nurses cannot refuse to provide nursing care for women, before or after the termination of the pregnancy (2013: 7).

On this view, indirect participation does not give rise to a 'genuine' objection because the objector is not proximate enough to the relevant act in order to be responsible for it. However, this legal and policy distinction has been coming under pressure internationally as those who believe themselves complicit in the provision of something morally objectionable have challenged the exclusion of indirect participation. Sepper (2014) distinguishes between what she calls first and second generation conscience clauses in the US, where the first are narrowly focused on certain professions and acts and the second concern broader protection of pharmacists and of information and referral activities. In a European context, this legal distinction has recently been considered by the Supreme Court in the UK in the context of Doogan and Wood. Irish law and policy has not explicitly considered the relevance of this distinction to any great extent yet (Medical Council, 2009: 16). But it informed the controversy surrounding the alleged right of pregnancy counselors, working in state funded services contracted out to Catholic organisations, not to provide clients with information about abortion services abroad (Fletcher 2013: 172).

In Doogan and Wood the Glasgow hospital appealed against the decision by the Inner House of the Scottish Court of Session that indirect participation in the form of supervision, delegation and support of staff providing abortion care did give rise to a right to conscientious objection under section 4 of the Abortion Act, 1967. Baroness 
Hale, delivering the unanimous judgment for the Supreme Court, identified the key legal issue as a specific one of statutory interpretation, rather than human rights or employment equality analysis. Ultimately she ruled that participation under section 4 would not on any view cover things done before the course of treatment began, such as making the booking before the first drug is administered. Moreover, a narrow meaning of actually taking part in a "hands-on capacity" was more likely to have been in contemplation by Parliament when the 1967 Act was passed (para 38). Therefore, managerial and supervisory tasks, including delegation, will not usually be covered by "participation". Support tasks will not be covered unless they involve assistance which entails actual hands-on participation in the termination. In other words, the SC decision is authority for the proposition that the legal distinction between direct and indirect participation cannot be considered solely from the subjective perspective of the conscientious objector. The question of participation ought to be decided objectively in terms of whether an action is actual, hands-on participation in termination of pregnancy. This approach is consistent with a court having regard to the proper objectives underpinning the lawful recognition of $\mathrm{CO}$, that is the legal protection of critical consciousness within a harm prevention framework.

The question of whether indirect participants merit recognition as conscientious objectors is best decided in terms of the good faith genuineness of their claim and secondly in terms of its reasonableness in the sense of being non-discriminatory. Some kinds of indirect abortion care (e.g. making arrangements for a woman who has decided to terminate her pregnancy, or handling foetal remains) may legitimately give rise to a 
$\mathrm{CO}$ because the objector genuinely believes that they would be complicit in something morally objectionable and may suffer a psychological harm as a result. This could be a belief that while a woman is entitled to make reproductive decisions and is entitled to reproductive healthcare, that professional does not want to be involved in the destruction of embryonic or foetal life because they believe that life has moral value from conception. As Kantymir and McLeod (2014) argue however, genuineness should not be a sufficient condition because reasons although genuine may be based on false information or they may be normatively problematic. As a matter of law, we should respond to this concern by adopting the regulatory assumption that a claim to $\mathrm{CO}$ is genuine, unless there is evidence to suggest otherwise. The belief that indirect forms of abortion care would make the carer complicit may be unreasonable, and if so they ought not be recognized as grounding a $\mathrm{CO}$ in law. Even if the objection is reasonable in the sense of being non-discriminatory, another question (discussed below), is whether other interests such as the needs of the woman limit the genuine and reasonable objection either by trumping it or by imposing conditions on its execution.

Objections to the provision of abortion information or genetic testing to a pregnant woman on grounds that it may contribute to an abortion decision and render the provider complicit in that decision should not stand because that may be an empirically false claim. For example, where an abortion decision has not been made, the objection to the test on the grounds that it could lead to abortion, is arguably factually incorrect. Results of a genetic test provide a woman with information about her pregnancy. This information may contribute to an abortion decision, but it is equally 
possible that it may not. Legal support for this approach can be found in the Colombian Court's opinion that indirect participation cannot ground CO "because of the difficulty in determining how their work interferes with legitimate moral, philosophical or religious convictions" (para 5.1). Before an abortion occurs, or before an abortion decision is made, we cannot know if care which provides a woman with information about her pregnancy and which has abortion as one possible outcome, will contribute to abortion or not, and we cannot say as a matter of fact if the objector is complicit or not. The issue arose in $R R v$. Poland (2011) 53 EHRR 31 (hereinafter $R R$ ), but was not definitively addressed by the European Court of Human Rights (ECtHR). The applicant argued that a refusal to provide a diagnostic test because that test might lead to abortion was not justified by CO. In particular her lawyers argued that

$[U]$ nder the established medical doctrine of informed consent, patients should be informed of all risks, benefits and alternatives to treatment in order to make a free and informed decision in their best interest. Refusing to diagnose a potentially serious illness on the basis that the diagnosis might subsequently lead to a therapeutic act to which the doctor concerned objected on grounds of conscience was incompatible with the very concept of conscientious objection (para 174).

In other words, patients who may be considering abortion are lawfully entitled to information and diagnostic tests about their pregnancy. Refusing to provide such 
information on the grounds that it is an aspect of abortion care is more than is necessary to protect the care provider's conscience. At the moment, pregnant women receiving care in Irish hospitals and crisis pregnancy centres, may not be getting full information about their pregnancy options. The women and couples of Termination for Medical Reasons have discussed 'feeling abandoned' by the Irish health care system on discovery that there were serious anomalies with their pregnancies (O'Carroll, 2013a). Good quality information about pregnancy options, including the availability of abortion care abroad, is provided in a variety of cases (Fletcher, 2013a). In other instances, women's access to abortion information is impeded either by the chilling effect of restrictions under the Regulation of Information (Services outside the state for termination of pregnancies) Act, 1995, or because relevant professionals are exercising a version of conscientious objection. I cannot review the issue in detail here, but the point I want to make for the purposes of this chapter is that if professionals are denying or delaying women access to information about their pregnancies out of a conscientious objection to abortion, that is unlikely to be a legitimate claim to CO because it makes incorrect assumptions about what women will do with that information.

Some forms of pre-abortion care ought not to give rise to CO because it will be unreasonable to deny pregnant women health information to which pregnant woman are normally entitled. Denying such information amounts to treating abortioncontemplating women as if they are not entitled to basic healthcare information, information which other patients receive. Objections which refuse to provide care for discriminatory or other normatively problematic reasons should not be legally 
recognized as engaging a right to CO (Medical Council, 2009: 16; General Medical Council, 2013b:para 8). Post abortion care is particularly likely to fall into this category because here the objector wants to withhold the care on the grounds that the woman has had an abortion. At this point it is not reasonable to understand this care as complicit in the provision of abortion because the abortion has happened. Rather here the refusal would be unjustifiably discriminatory because it is denying healthcare to women who have had abortions because of who they are, and not because of the action they may take. This might be the best interpretation of national laws in the UK and Italy which have, to date, explicitly excluded indirect involvement from the scope of CO (Doogan and Wood, 2014; European Social Committee, 2014). They are seeking to exclude those actions such as the non-provision of post-abortion care which amount to discrimination against women who have had abortions as less worthy of healthcare than other women or men. Some refusals of abortion care however, such as the supervision of abortion care in Doogan and Wood, are forms of indirect participation which are not obviously excluded as direct discrimination, but may be have to be legally limited in order to avoid harm to pregnant people.

\section{Harm reduction as a limit on conscientious objection}

Conscientious objection is a limited and not an absolute right (Pichon and Sajous v. France (2001) App. No. 49853/99, ECtHR; Lamacková, 2008; Daly, 2013). Most legal rights are limited by reference to the rights of others and public interests, but more extensive limitations are probably justifiable in the case of $\mathrm{CO}$. This is because $\mathrm{CO}$ arises out of a context where there is usually a lawful obligation on the objector to provide a 
form of healthcare, which conflicts with her conscience. Even though it is trite law that $\mathrm{CO}$ is a limited right, in practice health care professionals have been known to act as if their $\mathrm{CO}$ is absolute. The ECtHR felt the need to criticize the doctors in $P$ and $S$ v. Poland (2012) App. No. 57375/08 (hereinafter 'P and S') for effectively assuming an absolute right to CO (para 108). A more contested legal issue is not the fact of limitations per se, but the scope of such limitations and the kinds of harms that count in limiting CO. I will first examine the legal meaning of harm in this context (see further Erdman, 2011; Women's Link Worldwide, 2012) before considering the kinds of limits on CO that harm prevention entails.

\section{The scope of harms}

Most CO laws, including section 17 of the PLDPA, specify that healthcare professionals cannot rely on CO to deny a woman emergency life-saving abortion care (see further Department of Health, 2014: 40). Most CO laws also require timely referral to another provider if $\mathrm{CO}$ is being claimed in non- emergency situations. I argue that these kinds of legal limits on $\mathrm{CO}$ imply a recognition that $\mathrm{CO}$ could harm pregnant women in a variety of ways. How do we decide which harms count when considering the justifiable limits on $\mathrm{CO}$ ? When abortion law recognizes interests which may justify a termination of pregnancy it is recognising interests which may be harmed by the exercise of CO.

Therefore, the criteria for harms which limit CO are provided by the criteria for lawful termination. These will vary between legal regimes but typically range over women's interests in life, health, well-being, self-determination, dignity, freedom from degrading treatment and equality. If abortion laws recognize grounds for lawful abortion such as risk of injury to a woman's health and well-being, or a compromising of her self- 
determination and dignity, then these are legally recognized harms which limit the exercise of CO (see further IPPF-En v Italy, 2012). The harms which should count legally in calculating whether $\mathrm{CO}$ is limited in a particular case are all the harms anticipated by the legal measure permitting abortion and conscientious objection, not just the harm that is a life-threatening emergency. In an Irish context the harm of risk to life, including suicide risk, is recognized as a harm which grounds a legal right to abortion by the 2013 Act, and operates to limit the objections of those who disagree with abortion being provided on such grounds (see further Murray, 2013; Taylor, 2015; de Londras, 2015). Those who object to the provision of abortion on grounds of suicide risk do not have an absolute right to conscientiously object to such provision. Rather legal recognition of suicide risk as a ground for abortion means that any relevant $\mathrm{CO}$ has to be managed without becoming a barrier to lawful access on this ground.

A second issue is that the scope of abortion law may not be settled in relation to particular kinds of harms. At present the only harm, which is explicitly recognized as justifying lawful abortion in Ireland, is the harm of a real and substantial risk to a woman's life including the risk of self-destruction (Taylor, 2015). However, it is arguable that the Irish courts have not fully considered either the impact of women's ECHR rights, which now inform Irish domestic law (Egan et al, 2014); the proper scope of the legal term 'unborn' in the Constitution; the meaning of Article 40.3.3's reference to equality between woman and 'unborn'; or, the usual legal limits on the right to life. Although I cannot elaborate the argument fully here (see Fletcher 1998; 2008; 2013b), it is possible that a Court could expand the categories of lawful abortion in a particular fact situation 
and in light of lawful interests which were not in play when Attorney General $v$ X (1992)

1 IR 1 was decided. For example, it is not settled yet whether carrying a foetus with a fatal abnormality against a woman's better judgment is the kind of harm which could justify abortion. Although the current Attorney General does not agree (Kearns, 2015), it is possible that the 'right to life of the unborn' may not be engaged in such circumstances (Schweppe and Spain, 2013). It is possible that carrying such a pregnancy against one's will is a form of inhuman and degrading treatment justifying access to lawful abortion (RR; KL v Peru (UNHRC) CCPR/C/85/D/1153/2003; Centre for Reproductive Rights, 2014a; Centre for Reproductive Rights, 2014b). This means that it is also possible to invoke these harms as harms which may legally limit CO when contributing to the development of law and policy on CO in Ireland.

Harms which are explicitly recognized as legally justifying abortion ought to be recognised as harms which limit the exercise of CO. Given that the boundaries of legally recognised harms shift through argument and contestation, it is always possible that the category of harm that legally limits $\mathrm{CO}$ will be expanded or restricted. Even if the issue of what counts as harm is answered, there is still a question about the kind of limit such a harm may put on CO. In the section that follows I distinguish between legal recognition of harm reduction as a trump on $\mathrm{CO}$ and as a condition on CO. Harm reduction operates as a trump on $\mathrm{CO}$ when the right to $\mathrm{CO}$ is outweighed by the right underpinning access to abortion. Harm reduction imposes conditions on the exercise of any right to $\mathrm{CO}$ by requiring the objector to observe certain obligations e.g. referral that arise from the refusal to provide care. 


\section{Limits on $\mathrm{CO}$ as trumps or conditions}

When a CO law, such as section 17 of the PLDPA, specifies that health professionals cannot rely on CO to deny a woman emergency life-saving abortion care, it is recognizing that any prima facie right to $\mathrm{CO}$ will be trumped by the duty to reduce an imminent threat to the woman's life. It is not that the only harm which limits $\mathrm{CO}$ is a threat to a woman's life. Rather the effect of this threat of substantial harm is to act as a trump. The circumstances which trigger such a trumping of $\mathrm{CO}$ will usually be rare given that there must be no other way to accommodate the woman's interest in survival. In many circumstances, harm prevention will operate to impose conditions (rather than trumps) on CO so that the objector may only object or commit conscientiously when certain conditions are met.

Referral obligations, including those within section 17 PLDPA, are best

understood as conditions that are put on $\mathrm{CO}$ in order to prevent harm to the woman by delaying or inhibiting her access to lawful healthcare. In this way, the limiting of CO may translate into a series of standards and obligations, which objectors and the public health authorities which employ them, must meet (see further Campbell, 2009: 293; Dickens, 2014: 229). In effect, they should show that they are only breaching their duties to provide health care as far as is necessary in order to protect their critical consciousness. The emphasis on the need to guarantee access and eliminate any additional barriers that may arise in the exercise of $\mathrm{CO}$ (or its equivalent) is evident in the ECtHR's approach. This means that is for the physician and not the patient to meet 
the conditions. Recognised conditions, which implement the duty to provide unobstructed access to lawful abortion care, include referral, timeliness, adequate staffing and procedural regularity.

National laws and policies commonly recognize an objector's obligation to refer the patient to another professional who will treat her (GMC, 2013a: para 52; T-

388/2009: 34; Doogan and Wood 2014: para 40; Dickens 2014, 230). Westenson argues that a European regulatory standard of requiring the securing of referrals has been established as a result to the ECtHR decisions in $R R$ and $P$ and $S$ (2013). In $R R$ the failure to refer for genetic testing, which was required under domestic legislation, gave rise to a breach of the applicant's rights to freedom from inhuman and degrading treatment (protected by Article 3 ) and to private and family life (protected by Article 8 ). In $P$ and $S$ the failure to provide a referral for abortion was part of the applicants' evidence that they had not been provided with an effective means to exercise their rights under Articles 8 and 3 (para 81). Moreover, these failures to refer occurred in a context where domestic law imposed "on the doctor an obligation to refer the patient to another physician competent to carry out the same service" (para 107). The Health Service Executive has an obligation to ensure that objectors do refer women who have a lawful right to abortion on to other professionals in a timely manner.

The delays experienced by $R R$ and by $P$ and $S$ in trying to claim a lawful right to abortion were clear breaches of the standard of timeliness in access that is also required as a consequence of CO. In $R R$, it was 8 weeks after the request, and beyond the lawful time period for abortion, before she received the genetic test results. Secondly, the 
Court clearly saw the "procrastination, confusion and lack of proper counseling and information given to the applicant" in determining whether she should have access to genetic testing (para 153) as unnecessary barriers to access. Similarly in finding that P and S's ECHR rights were breached, the Court stated:

The events surrounding the determination of the first applicant's access to legal abortion were marred by procrastination and confusion. The applicants were given misleading and contradictory information. They did not receive appropriate and objective medical counselling which would have due regard to their own views and wishes. No set procedure was available to them under which they could have their views heard and properly taken into consideration with a modicum of procedural fairness (para 108).

The Court also noted that timeliness in the delivery of lawful health care was even more important in the context of pregnancy (para 111). The need to provide lawful abortion care in a timely manner operates as another reason why it may be illegitimate for hospitals, rather than individuals, to refuse the provision of abortion care on grounds of their institutional ethos. In order to meet a timeliness requirement, the hospital would have to show that another care provider at another institution could provide the lawful abortion without undue delay. In the Irish context where abortion is only lawful when it is life-saving, it will be very difficult for a hospital to show that transfer to another hospital meets the appropriate standard of timeliness.

The complaint against Italy raised a different kind of condition - adequate 
staffing - on the practice of conscientious objection (IPPF-EN, 2012; European

Committee of Social Rights, 2014). The successful argument here was that the state was failing to deliver appropriate standards of safe and lawful abortion because there was a dearth of personnel willing to provide abortion care in public hospitals. As a result the Committee decided that Italy had breached Article 11 of the European Social Charter, which protects the right to protection of health, in conjunction with the right to nondiscriminaton, protected by Article $\mathrm{E}$. The failure to regulate $\mathrm{CO}$ had contributed to the low number of abortion providers, which put a barrier in the way of women's access to lawful abortion, making the whole safe and timely service unsustainable. As Raz observes "The conscientious exemption from a duty to participate in administering the right is allowed because, and so long as, it does not threaten the provision of the service." (2013: 3) This understanding is also supported by the reasoning of the Colombian Constitutional Court in Decision T-388/2009 (2014). The Court was unequivocal in stating that the rights of pregnant women were not protected when the State or the governmental system responsible for healthcare insurance (EPS) fails to ensure the presence of a sufficient number of health care professionals (section 5.1).

The need to prevent harm places formal as well as substantive limits on CO. Regulators need to ensure that proper procedures are in place in order to guide the exercise of $\mathrm{CO}$ and allow objectors protection of their critical consciousness while ensuring that public health and women's interests are appropriately protected. Westenson argues that a European regulatory standard of requiring refusals in writing has been established as a result of the ECtHR decisions in $R R$ and $P$ and $S$ (2013). This 
documentation should include the reasons for the refusal and an appropriate referral. The Colombian Constitutional Court provided some further guidance on the standard required of refusals when it specified that the objector must explain why "performing the abortion in this specific case goes against her most intimate convictions" and notes that "general language presented on behalf of a group will not suffice, nor objections presented by any person other than the person who is conscientiously objecting" (T$388 / 2009,2014: 43)$. This provides a procedural means for enabling regulators to check for bad faith and discriminatory reasons.

\section{Conclusion}

Struggles for social justice in neighbourhoods the world over have emphasized the need to differentiate between claims to freedom and conscience. A hospital's public statement that it will not allow abortion to be performed on its premises, is not the same claim as that of the individual midwife who refuses to perform an abortion, but continues to care for her patients otherwise. Moreover if that hospital takes public funding on the one hand, but asserts the private values of a particular religion or secular ethos on the other, this is not the critical expression of moral freedom, but a kind of macho politics. Such a hospital is saying that it is entitled to public funding and state support, but is not publicly accountable. Institutional power needs to be revealed for what it is, not accepted on its own terms (see further: McGuinness and Thomson, 2015). Similarly, the articulation of a doctrinal religious viewpoint, which has long been institutionalized, is not the same as the expression of a critical moral view which stands 
against the legal status quo perhaps at some personal cost. We do a disservice to the many moral and religious traditions which have struggled against disadvantage with few resources, if we accept dominant religious powers' efforts to characterize themselves as marginal and weak. Conscientious objectors ought to be recognized, but do need to be held accountable to public obligations to prevent harm. This is part of the struggle to preserve critical spaces against, and within, institutional power in its new and varied forms.

\section{References}

Campbell, Mark (2011a) 'Conscientious objection, health care and Article 9 of the European Court of Human Rights' Medical Law International 11: 284-304

Campbell, Mark (2011b) 'Conscientious objection and the Council of Europe', Medical Law Review 19: 467-475

Casey, Patricia (2013), Submission to the Public Hearings on the Implementation of the Government Decision following the publication of the Expert Group Report into matters relating to A, B, C, vs Ireland, 8 January, available at:

http://www.oireachtas.ie/parliament/media/committees/healthandchildren/PatriciaCaseySubm ission.pdf 
Centre for Reproductive Rights (2014a) Abandoned and Stigmatised: The Impact of the Irish Abortion Law on Women

http://reproductiverights.org/sites/crr.civicactions.net/files/documents/AbandonedAndStigmati zed_ImpactOfIrishAbortionLaw.pdf

Centre for Reproductive Rights (2014b), Centre for Reproductive Rights brings second case against Ireland's Abortion laws to United Nations http://reproductiverights.org/en/pressroom/CRR-brings-second-Ireland-case

Coen, Mark (2013) 'Abortion Law may run Counter to Constitution' The Irish Times 8 August.

Corbin, Mala (2014) 'Abortion Distortions' William and Lee Law Review forthcoming, prepublication copy available at: http://papers.ssrn.com/sol3/papers.cfm?abstract_id=2375783

Daly, Eoin (2013) 'Religious freedom arguments in the abortion debate' Human Rights in Ireland Blog, 12 August

http://humanrights.ie/civil-liberties/religious-freedom-arguments-in-the-abortiondebate/?utm_source=feedburner\&utm_medium=email\&utm_campaign=Feed\%3A+humanright s\%2FkxLu+\%28Human+Rights+in+Ireland\%29

Daly, Eoin (2012), Religion, Law and the Irish State (Dublin: Clarus Press).

De Londras, F. (forthcoming 2015) 'Constitutionalising Fetal Rights: A Salutary Tale from Ireland' Michigan Journal of Gender and Law 22(2) 
Department of Health (2014) Implementation of the Protection of Life During Pregnancy Act 2013: Guidance Document for Health Professionals

Dickens, Bernard (2014) 'The Right to Conscience' in Rebecca Cook, Joanna Erdman and Bernard Dickens (eds.) Abortion Law in Transnational Perspective Philadelphia: University of Pennsylvania Press, pp 210-238.

Dickens, Bernard and Cook, Rebecca (2011) 'Conscientious Commitment to Women's Health' International Journal of Gynecology and Obstetrics 113(2): 163-166; available at: http://papers.ssrn.com/abstract=1832549

Dickens, Bernard (2006) 'Conscientious Objection: A Shield or a Sword?' in S.A.M. McLean, ed. First Do No Harm: Law, Ethics and Healthcare (Aldershot, UK: Ashgate) 337-351

Doctors for Choice (2014) Submission to the UNHRC for Ireland's Review under the ICCPR; available http://www.ccprcentre.org/doc/2014/06/INT_CCPR_CSS_IRL_17440_E.pdf

Egan, Suzanne, Thornton, Liam and Walsh Judy (2014) Ireland and the European Convention on Human Rights: 60 years and beyond (Bloomsbury: Dublin)

Erdman, Joanna (2011) 'Access to Information on Safe Abortion: A Harm Reduction and Human Rights Approach' Harvard Journal of Law and Gender 34: 413-462; available at http://papers.ssrn.com/sol3/papers.cfm?abstract_id=1884387 
European Parliamentary Assembly (2010), Resolution 1763

http://assembly.coe.int/ASP/XRef/X2H-DW-XSL.asp?fileid=17909\&lang=EN

European Committee of Social Rights (2014), Decision on the Merits No. 87/2012 in the complaint International Planned Parenthood Federation European Network (IPPF EN) v. Italy http://www.coe.int/t/dghl/monitoring/socialcharter/NewsCOEPortal/CC87Merits_en.asp

Fiala, Christian and Joyce Arthur (2014) "Dishonourable disobedience" - why refusal to treat in reproductive healthcare is not conscientious objection, Woman - Psychosomatic Gynaecology and Obstetrics 1: 12-23; available http://dx.doi.org/10.1016/j.woman.2014.03.001

Fletcher, Ruth (2014) 'Conscientious Objection and Harm Reduction in Europe' in T-388/2009 Conscientious Objection and Abortion: A Global Perspective on the Colombian Experience, O'Neill Institute for National and Global Health Law and Women's Link Worldwide, 124-146 available at: http://www.womenslinkworldwide.org/wlw/new.php?modo=detalle_proyectos\&tp=publicacio $\underline{\text { nes\&dc }=74}$

Fletcher, Ruth (2013a) 'Peripheral Governance: Administering Transnational Healthcare Flows' International Journal of Law in Context 9: 161-190 ; available at http://papers.ssrn.com/sol3/papers.cfm?abstract_id=2395895

Fletcher, Ruth (2013b) Submission to the Health Committee on the General Scheme of the Protection of Life During Pregnancy Bill, 2013, in Houses of the Oireachtas Joint Committee on 
Health and Children, Report on Protection of Life During Pregnancy Bill 2013 (Heads of) (Volume 1) May $2013402-412$

http://www.oireachtas.ie/parliament/media/committees/healthandchildren/Volume1.pdf2013 and http://blogs.ucc.ie/wordpress/ccjhr/2013/05/24/629/

Fletcher, Ruth (2008) "Reproductive Justice and Article 403 3", in Jennifer Schweppe ed. The Unborn Child, Article 4033 and Abortion in Ireland: 25 years of Protection? (Dublin: Liffey Press) 319-348

Fletcher, Ruth (1998) “'Pro-Life' Absolutes, Feminist Challenges: The Fundamentalist Narrative of Irish Abortion Law 1986-92", Osgoode Hall Law Journal 36: 1-62

Gallagher, C.T. A. Holton, L. J. McDonald, P. J. Gallagher (2013) 'The fox and the grapes: an Anglo-Irish perspective on conscientious objection to the supply of emergency hormonal contraception without prescription' Journal of Medical Ethics 39: 638-642 2013; DOI:

10.1136/medethics-2012-100975;

http://uhra.herts.ac.uk/bitstream/handle/2299/11838/The_Fox_and_the_Grapes_vR1a.pdf?seq uence $=2$

General Medical Council (2013a) Good Medical Practice http://www.gmcuk.org/guidance/good_medical_practice.asp

General Medical Council (2013b), Personal Beliefs and medical practice, http://www.gmcuk.org/static/documents/content/Personal_beliefs_and_medical_practice.pdf_51462245.pdf 
Holland, Kitty (2013) 'Mater Hospital to comply with legislation' The Irish Times 25 September http://www.irishtimes.com/news/social-affairs/mater-hospital-to-comply-with-legislation-

\subsection{1}

International Planned Parenthood Federation - European Network v Italy, Complaint No $87 / 2012$

http://www.coe.int/t/dghl/monitoring/socialcharter/Complaints/CC87CaseDoc1_en.pdf

Joffe, Carole (1996), Doctors of Conscience (Boston, Beacon Press)

Kantymir, Lori and Carolyn McLeod (2014), “Justification for Conscience Exemptions in Health Care" Bioethics 28(1): 16-23

Kearns, D. (2015) 'Clare Daly calls for Attorney General Advice to be published after fatal foetal abnormality bill defeated' The Independent 10 February; http://www.independent.ie/irishnews/politics/clare-daly-calls-for-attorney-general-advice-to-be-published-after-fatal-foetalabnormality-bill-defeated-30981598.html

Kelleher, J Paul (2010), 'Emergency Contraception and Conscientious Objection' Journal of Applied Philosophy 27(3): 290-304

Lamackova, Adriana (2008) "Conscientious Objection in Reproductive Health Care: Analysis of Pichon and Sajous v. France." European Journal of Health Law, 15(1): 7-43 
McGuinness, S. and Thomson, M. (2015) 'Medicine and Abortion Law: Complicating the Reforming Profession' Medical Law Review 23(2): 177-199.

Medical Council (2009) Guide to Professional Conduct and Ethics ( $7^{\text {th }}$ edition)

Melling, Louise and Jennifer Lee (2014), 'Lessons from Colombia to the United States' in T388/2009 Conscientious Objection and Abortion: A Global Perspective on the Colombian Experience (Washington and Bogota: O'Neill Institute for National and Global Health and Women's Link Worldwide) 111-122

Montgomery, J (2015) 'Conscientious Objection: Personal and Professional Ethics in the Public Square' Medical Law Review 23(2): 200-220

Murphy Mark (2014) Abortion law strangled at birth by medical guidelines. The Irish Independent. 9 August.

Murray Claire (2013) The narrative of the hysterical woman: the discourse on the inclusion of suicide in the Irish legislation on abortion. Reforming Abortion Law: Comparative Perspectives Conference, University College Cork, 22 March http://rightsni.org/2013/01/legislating-forarticle-40-3-3-murray-on-hysterical-women/ 
Neal, Mary (2014), 'Commentary: the scope of the conscience-based exemption in section 4(1) of the Abortion Act 1967: Doogan and Wood v NHS Greater Glasgow and Clyde Health Board [2013] CSIH 36' Medical Law Review 22(3): 409-421

O’Brien, Breda (2013) "Mater Hospital nuns must stand up to bullying" The Irish Times, 5 October

O'Carroll, Sinead (2013a) 'Emotional plea for change: Wrap your arms around us, don't kick us out' The Journal, 13 November

O'Carroll, Sinead (2013b) 'Mater hospital says it will comply with new abortion laws' The Journal. 15 September.

Raz, Joseph (2013) 'Death in our Life', Journal of Applied Philosophy 30(1): 1-11

Raz, Joseph (2009) The Authority of Law (Oxford, Oxford University Press)

Royal College of Nursing (2013), Termination of Pregnancy: A Nursing Framework http://www.rcn.org.uk/_data/assets/pdf_file/0004/529654/Termination_of_pregnancy_WEB. pdf

Savulescu, Julian (2006) 'Conscientious objection in medicine' British Medical Journal 332: 294297 
Schweppe, Jennifer and Spain, Emer (2013) 'When is a Foetus not an Unborn? Fatal Foetal Abnormalities and Article 403 3' Irish Journal of Legal Studies 3(3): 92-110 http://ijls.ie/?p=381

Sepper, Elizabeth (2014) "Doctoring Discrimination in the Same Sex Marriage Debates" Indiana Law Journal 89: 703

Sepper, Elizabeth (2013) "Contraception and the Birth of Corporate Conscience", Washington University in St. Louis Legal Studies Research Paper; available at: http://papers.ssrn.com/sol3/papers.cfm?abstract_id=2289383

Sepper, Elizabeth (2012), "Taking Conscience Seriously", Virginia Law Review 98: 101; available at: http://papers.ssrn.com/sol3/papers.cfm?abstract_id=1888375

Taylor, M. (2015) 'Women's Right to Health and Ireland's Abortion Laws' International Journal of Gynaecology and Obstetrics 130: 93

T-388/2009 Conscientious Objection and Abortion: A Global Perspective on the Colombian Experience, Washington and Bogota: O’Neill Institute for National and Global Health Law and Women's Link Worldwide, 2014 available at:

http://www.womenslinkworldwide.org/wlw/new.php?modo=detalle_proyectos\&tp=publicacio $\underline{\text { nes } \& d c=74}$ (no authors identified as such)

Thomson, Michael (2013) "Abortion Law and Professional Boundaries" Social and Legal Studies 22(2): $191-210$ 
Westeson, Johanna (2013) "Reproductive health information and abortion services: Standards developed by the European Court of Human Rights" International Journal of Gynecology and Obstetrics 122: 173-176

Whyte, Gerry (2013) Five issues could prompt referral of abortion legislation to Supreme Court The Irish Times. http://www.irishtimes.com/news/politics/five-issues-could-prompt-referral-ofabortion-legislation-to-supreme-court-1.1466620

Wicclair M (2011) Conscientious Objection in Healthcare: An Ethical Analysis. Cambridge University Press

Women's Link Worldwide (2012) Maternal Mortality, Unsafe Abortion and the Harm Reduction Model: The Legal Platform; available at http://www.womenslinkworldwide.org/wlw/new.php?modo=detalle_proyectos\&dc=66 